The Computer Handbook 
Other Macmillan books of related interest

Computer Literacy: A beginners' guide Vincent Walsh

Dictionary of Information Technology Dennis Longley and Michael Shain Making Computers Work Trevor J. Bentley

Mastering Computers G. Wright

The Microcomputer Users Handbook Dennis Longley and Michael Shain Understanding Microcomputers Dennis Longley and Michael Shain 


\section{The \\ Computer Handbook}

A businessman's guide to choosing and using

a computer system

\section{Charles Jones}

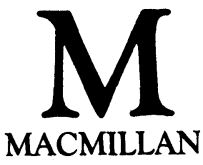




\section{๑) Charles Jones 1986}

All rights reserved. No reproduction, copy or transmission of this publication may be made without written permission.

No paragraph of this publication may be reproduced, copied or transmitted save with written permission or in accordance with the provisions of the Copyright Act 1956 (as amended).

Any person who does any unauthorised act in relation to this publication may be liable to criminal prosecution and civil claims for damages.

First published 1986

Published by

MACMILLAN EDUCATION LTD

Houndmills, Basingstoke, Hampshire RG21 2XS

and London

Companies and representatives

throughout the world

British Library Cataloguing in Publication Data

Jones, Charles

The computer handbook: a businessman's guide

to choosing and using a computer.

1. Microcomputers-Catalogs

I. Title

$001.64^{\prime} 04^{\prime} 0294 \quad$ QA76.5

ISBN 978-0-333-39263-8 ISBN 978-1-349-07991-9 (eBook)

DOI 10.1007/978-1-349-07991-9 
This book is dedicated to William Jones, Senior and Junior, who made it all possible 
Although this may seem a paradox, all exact science is dominated by the idea of approximation

Bertrand Russell 


\section{Contents}

(Italic heads indicate illustrative sections for use as reference material)

Introduction

The first step is the biggest

"Is this actually a revolution?"

Development of office technology

The 'generations' of computer development

1 The New Role for Management 10

$\begin{array}{ll}\text { The new skills } & 10\end{array}$

Flowcharting 13

Decision tables $\quad 14$

A 'system' 17

Why bother with computers? 19

Possible areas where compute; systems can 'earn their keep' 20

The time trap 22

Office productivity 23

The hierarchy of systems 25

New technology and the human interface 28

Recruitment 31

Education $\quad 32$

$\begin{array}{ll}\text { Computer Aided Engineering (CAE) } & 36\end{array}$

2 Computer Equipment 38

The evolution of computers $\quad 38$

$\begin{array}{ll}\text { Computer configurations } & 40\end{array}$

Benchmarks 41

What's in a word $\quad 44$

Boolean logic and the binary system of counting 46

The mainframe 48

Computer level bus services $\quad 50$

The development of the microchip $\quad 54$

The different microprocessors $\quad 56$

Typical layout of a microcomputer's electronics 58 
How internal memory can be used in microcomputers 60

Types of data storage access $\quad 63$

Access times and cache memory $\quad 65$

$\begin{array}{ll}\text { Printers and plotters } & 67\end{array}$

$\begin{array}{ll}\text { Impact printers } & 67\end{array}$

Printing technologies 1 $\quad 69$

$\begin{array}{ll}\text { Non-inpact printers } & 71\end{array}$

$\begin{array}{ll}\text { Printing technologies 2 } & 72\end{array}$

$\begin{array}{ll}\text { Printing tips } & 74\end{array}$

Terminals, monitors, VDUs, displays and keyboards $\quad 75$

Display check-list and the technology 76

$\begin{array}{ll}\text { Man-machine interface } & 81\end{array}$

The ASCII and EBCIDIC codes $\quad 82$

Optical character recognition and facsimile exchange 84

$\begin{array}{ll}\text { Bar Codes } & 85\end{array}$

Information on plastic cards, OCR \& FAX 86

$\begin{array}{ll}\text { Telex, Teletex and Teletext } & 87\end{array}$

Communications terminology and Prestel 88

$\begin{array}{ll}\text { Communications } & 91\end{array}$

Local and Wide Area Networks 99

Digital, analogue and modulated signals 94

Communications techniques and terminology 95

RS232C serial connection and associated protocols 96

The ISO 7-layer communications model 99

3 Software $\quad 101$

$\begin{array}{ll}\text { What it is } & 101\end{array}$

$\begin{array}{lr}\text { The different levels of software } & 103\end{array}$

$\begin{array}{lr}\text { Program suites and packages } & 105\end{array}$

What would you see if you could read a disk? $\quad 108$

The database concept $\quad 112$

$\begin{array}{lr}\text { Programming concepts } & 114\end{array}$

$\begin{array}{lr}\text { Computer languages } & 115\end{array}$

$\begin{array}{lr}\text { Operating systems } & 122\end{array}$

Multi-user and multi-tasking systems 123

$\begin{array}{lr}\text { Microcomputer configurations } & 126\end{array}$

$\begin{array}{lr}\text { The cost of software } & 129\end{array}$

$\begin{array}{lr}\text { The price you pay for software } & 130\end{array}$

$\begin{array}{lr}\text { Piracy } & 132\end{array}$

$\begin{array}{ll}\text { Problems and pitfalls } & 133\end{array}$

$\begin{array}{ll}\text { Future developments } & 135\end{array}$

$\begin{array}{ll}\text { Windows, icons, mice and pointers } & 138\end{array}$

$4 \quad$ Selecting a System $\quad 141$

An overview of package selection $\quad 142$

$\begin{array}{ll}\text { The strategy } & 144\end{array}$ 
The feasibility study

Strategies

Strategies - another perspective

The interdependence of files

Preparing the specification

Outline specification

Summary of the various alternatives

Configurations of typical small business systems

Dealer check-list

Evaluating and selecting software

A check-list for sorting out the short-list

Software evaluation

Selecting hardware

Reading a computer specification

Outline and costing of some possible strategies

Choosing printers

Estimating bulk data storage requirements

Choosing a printer

The economics of choosing small printers

Spooling, buffering and the production of characters

Dealing with data-processing managers

How to link to a mainframe from a micro 189

Project management

Connecting to bulletin boards

How to make a small system work $\quad 194$

Project flowchart

Designing a computer system

5 Working with Computers 198

$\begin{array}{ll}\text { Training } & 198\end{array}$

Floppy disks 200

Staff relations 203

Physical preparations 204

Form design and numbering systems 206

Installing, testing and data conversion $\quad 209$

Installing and testing: who does what $\quad 210$

$\begin{array}{ll}\text { Installing hardware } & 212\end{array}$

$\begin{array}{ll}\text { File transfer } & 216\end{array}$

Communications protocols and how to set up communication links 217

Routine tasks

Data Protection Act

Cryptography: DES and the open key 224

Back-up procedures: disks $\quad 226$

Audit trails $\quad 230$

Paper handling 233

Types of paper feed $\quad 234$ 
Some 'Dos' and 'Don'ts'

Time-scales

The main factors affecting time-scales

The human factor

Priorities

Ergonomics

The working environment

The laws of computing!

Cost-benefit analysis overview

Project costing check-list

Explaining the costs of different strategies

Benefits

Hidden extras

Buying and financing

What you pay is important

Cost of storage

The capacity of disk drives and disks

The contract

Running costs

Insurance

Charging for computer services

Setting the cost of a central computer

7 An Outline of Some Standard Packages

Word processing

Word-processor check-list

Spreadsheet calculators

Spreadsheets and model builders

Model building

How to use them

Database - what is it?

8 The Office of the Future 305

Terminology 305

The ideal office 305

Some practicalities underlying office automation 306

Office time budget

Where the technology can help

Office system integration

Central versus distributed processing; bandwidth and satellite communications

Working in the office of the future 
Working from home

Different hardware strategies

317

Artificial intelligence

Expert Systems

Artificial intelligence and 5th generation computing

Appendix A: System Questionnaire

Appendix B: Bibliography and Where to Find More to Read

Appendix C: List of Journals and Publications

Appendix D: Sources of Help and Advice

Appendix E: Supplier Address List 
$\mathrm{CP} / \mathrm{M}$ and MP/M are the registered trade marks of Digital Research Inc.

IBM and SNA are the registered trade marks of International Business Machines Corporation.

PRESTEL is the registered trade mark of British Telecom.

DEC is the registered trade mark of the Digital Equipment Company.

Unix is the registered trade mark of Bell Laboratories.

MSDOS, XENIX and MSX are the registered trade marks of Microsoft Inc. 